\title{
On-station performance evaluation of improved tropically adapted chicken breeds for smallholder poultry production systems in Nigeria
}

\author{
O. Bamidele $^{1}$ (1) $\cdot$ E. B. Sonaiya ${ }^{1} \cdot$ O. A. Adebambo ${ }^{2} \cdot$ T. $^{\text {Dessie }}{ }^{3}$
}

Received: 23 August 2019 / Accepted: 18 November 2019 / Published online: 8 December 2019

(C) The Author(s) 2019

\begin{abstract}
Background Availability of appropriate genetics is important for the development of smallholder poultry (SHP). The biological potential of improved dual purpose chicken germplasms was evaluated in Nigeria.

Methods A total of six breeds (Fulani, FUNAAB Alpha, Kuroiler, Noiler, Sasso, and Shika-Brown) were tested on-station, in deep litter houses at two test centres (Public and private facility) for 504 days. Birds were fed ad libitum for the first 140 days after which restricted feeding was practised.

Result Lowest and highest hatchability of eggs set was 55\% (FUNAAB Alpha) and 89\% (Sasso), respectively. At 140 days, male live weights were 200\%-300 \% higher than the local chickens (975 g) except Shika-Brown (152\%) and Fulani (135\%). Lowest $(p<0.05)$ age at first egg was 119 days for Shika-Brown and 120 days for FUNAAB Alpha and Kuroiler. Highest hen-housed egg production was 192 for Shika-Brown, and feed intake per dozen eggs was lowest $(p<0.05)$ for Shika-Brown $(2.9 \mathrm{~kg})$ and FUNAAB Alpha $(2.9 \mathrm{~kg})$. Mortality rate of the locally sourced breeds (Fulani, FUNAAB Alpha, Noiler, and Shika-Brown) was significantly lower $(p<0.05)$ than the foreign-sourced breeds (Kuroiler, Sasso) during brooding, growing and laying.

Conclusion Results from this study identified FUNAAB Alpha and Noiler as being more suitable for dual-purpose functions (egg and meat), while Sasso and Kuroiler (meat) and Shika-Brown (egg) were observed to be better suited for single purpose functions. These findings could guide the introduction of smallholder poultry-specific hybrid germplasms for the development of the smallholder poultry production systems in Nigeria.
\end{abstract}

Keywords Chickens $\cdot$ Smallholder poultry $\cdot$ On-station $\cdot$ Dual-purpose $\cdot$ Breeds

\section{Introduction}

Smallholder poultry (SHP) is defined as poultry keeping by households using family labour, locally available feed resources obtained largely through scavenging by a flock of less than 100 birds, of unimproved or improved breed (Sonaiya, 1990). The characteristics and importance of SHP are fundamentally similar in rural and peri-urban farming communities irrespective of the sociocultural factors and agroecological

O. Bamidele

bamideledeji@gmail.com

1 African Chicken Genetic Gains, c/o Department of Animal Sciences, Obafemi Awolowo University, Ile, Ife, Nigeria

2 Department of Animal Genetics and Breeding, Federal University of Agriculture, Abeokuta, Nigeria

3 International Livestock Research Institute, Addis Ababa, Ethiopia conditions (FAO, 2010). The low productivity of the SHP production systems (as characterized by high mortality, low egg numbers, and poor live performance) has resulted in the demand by SHP producers for "better and bigger" birds in Nigeria (ACGG Nigeria baseline data, 2016). Such "better" birds are best provided not by commercial/industrial poultry germplasms but by SHP-specific hybrid germplasms (SHPSHG) which are improved dual-purpose birds (meat and egg production) that incorporate genes for higher productivity and performance into the hardiness of locally adapted chickens.

The introduction of SHP-SHG has been successfully tested on-farm, under scavenging management systems (i.e. Backyard poultry), in Bangladesh for the Sonali chickens (FAO, 2015), and in Uganda with the Kuroiler (Galukande et al., 2016; Sharma et al., 2015). However, under the African Chicken Genetic Gains project in Nigeria, the testing of six SHP-SHG (Fulani, FUNAAB Alpha, Noiler, Kuroiler, Sasso, and ShikaBrown) was conducted both on-farm, as a farmer-led experimentation, and on-station (https://africacgg.net). The on-station 
research condition (controlled environment) was adopted as an evidenced-based approach of investigating the biological potential of SHP-SHG under intensive management systems, with optimum feeds and feeding, housing, biosecurity, and health measures. Hence, the objective of this study was to evaluate the growth performance, egg production, and mortality rate of the selected SHP-SHG, under on-station conditions in Nigeria.

\section{Material and methods}

\section{Study locations}

The on-station test was conducted at a private (Fol-Hope Farms, Ibadan, Oyo State) and public (Federal University of Agriculture, Abeokuta, Ogun State - FUNAAB) facility located within the southern Guinea savanna, and dry lowland rainforest of Nigeria, respectively. The birds were tested in isolated poultry houses sited away from other birds at the test centres. The coordinates of the two test centres, within the respective agroecologies, were: latitude $7^{\circ} \mathrm{N} 20^{\prime} 25^{\prime \prime}$, longitude $3^{\circ} \mathrm{E} 58^{\prime} 14^{\prime \prime}$ and altitude $4.5 \mathrm{~m}$ (Fol-Hope station), and latitude $7^{\circ} \mathrm{N} 13^{\prime} 28^{\prime \prime}$, longitude $3^{\circ} \mathrm{E} 26^{\prime} 3^{\prime \prime}$ and altitude $133.8 \mathrm{~m}$ (FUNAAB station). Testing of the breeds commenced in May 2016, and lasted for 72 weeks. During the test period, the minimum and maximum temperature $\left({ }^{\circ} \mathrm{C}\right)$ at Fol-Hope was $17.8^{\circ} \mathrm{C}$ and $36.4{ }^{\circ} \mathrm{C}$, while at FUNAAB it was $18.3^{\circ} \mathrm{C}$ and $39.7^{\circ} \mathrm{C}$. Average daily temperature $\left({ }^{\circ} \mathrm{C}\right)$ ranged from 30.9 ${ }^{\circ} \mathrm{C}$ (Day)-23.1 ${ }^{\circ} \mathrm{C}$ (Night) at Fol-Hope, and 33.1 ${ }^{\circ} \mathrm{C}$ (Day)$26.4{ }^{\circ} \mathrm{C}$ (Night) at FUNAAB. The average annual rainfall $(\mathrm{mm})$ and relative humidity $(\%)$, at Fol-Hope and FUNAAB test stations, were $1345.5 \mathrm{~mm}$ and $79.5 \%$ and $1030.1 \mathrm{~mm}$ and $84.4 \%$, respectively (NiMET, 2019).

\section{Experimental birds and management}

Hatchable eggs of the locally sourced breeds (Fulani, FUNAAB Alpha, Noiler and Shika-Brown) were purchased from the respective breeder farms (1st Agro Limited, Abeokuta, Ogun State; PEARL Poultry Unit, FUNAAB, Ogun State; and Amo Farms Sieberer Hatchery Limited, Awe, Oyo State, and Fol-Hope Farms Limited, Ibadan, Oyo State) within the country. International veterinary certificates were obtained from the Federal Department of Veterinary and Pest Control Services, Federal Ministry of Agriculture and Rural Development (FMARD), Abuja, Federal Capital Territory for the importation of hatchable eggs, of Kuroiler from Chick Masters Limited, Mukono, Uganda (FDL/BHE/ 12/16), and Sasso, from Silverlands Tanzania Limited, Iringa, Tanzania (FDL/BHE/11/16). All the chicks were hatched onstation, and a total of 1,939-day-old chicks of both locally sourced breeds and foreign-sourced breeds were brooded from 0 to 42 days (d). The birds were sexed at 42 days, and grown separately until 140 days for males and 504 days for females. The population density was 10 chicks $/ \mathrm{m}^{2}, 7 \mathrm{birds} / \mathrm{m}^{2}$, and 5 birds $/ \mathrm{m}^{2}$ during brooding, growing, and laying phases, respectively. Commercial feed (Chick mash: 2,993 kcal ME/kg, $22.3 \% \mathrm{CP}$; Grower mash: 3,013 kcal ME/kg, 17\% CP) and water were available ad libitum during brooding and growing phases. During the laying phase (Layer mash: 2,500 kcal ME/ $\mathrm{kg}, 16.5 \% \mathrm{CP}, 3.6 \% \mathrm{Ca}$ ), hens were restricted to a maximum of $120 \mathrm{~g} \mathrm{feed/hen/day.} \mathrm{Standard} \mathrm{biosecurity} \mathrm{measures} \mathrm{and}$ vaccination schedules were observed at the test centres. This study was approved by the International Livestock Research Institute Institutional Animal Care and Use Committee (ILRI IACUC) with reference number: IACUC-RC2016.26.

\section{Data collection and analysis}

Fertility and hatchability percentages were determined from hatchery performance record taken at day 1 (eggs set), day 18 (candling), and day 21 (hatching). Data on feed intake, egg production, and mortality were taken daily. Body weights were measured every 14 days. For males, bodyweights were taken until 140 days when final live weights were obtained for meat production. For females, all measurements were taken up till 504 days, with particular interest in egg production. The temperature humidity index (THI), as an indicator of heat stress, was determined and categorised (normal: $<27.8$, moderate: 27.8-28.8, severe: $28.9-29.9$, and very severe: $\geq 30.0$ ) as described by Lallo et al. (2018). This study was conducted independently in each of the test stations as a randomised complete block design (RCBD) of 4 replicates (pens) per breed. The dimension of the pens was $1.8 \mathrm{~m} \times 1.3 \mathrm{~m}$. Growth rate, feed conversion ratio (FCR), hen-housed egg production (HHEP), hen-day egg production (HDEP), and mortality rate were analysed using a twoway analysis of variance, with breed and location as factors (SAS university edition). Differences between means were separated using Duncan's multiple range test.

\section{Results}

Table 1 shows the hatchery performance. Hatchability of the locally sourced breeds was $68.2 \%$, while that of the foreignsourced breeds was $70 \%$. Hatchability of eggs set (HES) ranged from $55 \%$ (Fulani and FUNAAB Alpha) to $84 \%$ (Noiler). Hatchability of fertile eggs (HFE) was $80 \%$ and above, in all the breeds, except Fulani (72\%).

Table 2 shows the live weight performance of the breeds. Bodyweight gain and FCR of the breeds differed $(p<0.05)$ significantly during brooding, growing, and laying. Noiler had the lowest FCR at brooding (2.2), while FCR for Kuroiler (7.5) and Sasso (7.6) were lowest during growing for males. For growing females, Kuroiler (9.8), Noiler (9.7), and Sasso (9.8) had the lowest FCR but were not significantly 
Table 1 Hatchability of eggs of the six breeds

\begin{tabular}{lllll}
\hline Breeds & Eggs set* & Number fertile & $\begin{array}{l}\text { Hatchability \% } \\
\text { of eggs set (HES) }\end{array}$ & $\begin{array}{l}\text { Hatchability \% of } \\
\text { fertile eggs (HFE) }\end{array}$ \\
\hline Fulani & 8,187 & 6,275 & 55 & 72 \\
FUNAAB Alpha & 13,688 & 9,153 & 55 & 82 \\
Kuroiler & 24,480 & 20,521 & 67 & 80 \\
Noiler & 11,905 & 11,190 & 84 & 89 \\
Sasso & 93,992 & 79,629 & 71 & 84 \\
Shika-Brown & 23,157 & 20,911 & 77 & 85 \\
\hline
\end{tabular}

*Total number of eggs set for both on-station and on-farm test different. Male bodyweight for Sasso $(2,962.1 \mathrm{~g})$ and Kuroiler $(2,894.2 \mathrm{~g})$ was higher $(p<0.05)$ than Noiler $(2,599.0 \mathrm{~g})$, while FUNAAB Alpha $(2,097.0 \mathrm{~g})$ differed $(p<0.05)$ from Shika-Brown (1688.4 g) and Fulani (1321.0 g). At 504 days, Sasso had the highest live weight (2634.4 g) but did not differ $(p<0.05)$ from Kuroiler $(2422.0 \mathrm{~g})$, and Noiler $(2355.1 \mathrm{~g})$. Also, FUNAAB Alpha $(2132.7 \mathrm{~g})$ was similar $(p<0.05)$ to Kuroiler, Noiler, Sasso, and Shika-Brown (2045.7 g) but higher than Fulani (1740.2 g). The genotype by environment interaction on final bodyweight and FCR across the rearing phases was not significant $(p<0.05)$, except for the FCR during growing for females.

Tables 3 and 4 show the laying performance. The genotype by environment interaction was significant $(p<0.05)$ for all the parameters, except egg weight (Table 3 ). The mean ages at first egg, egg weight, and HHEP in 364 days were 125 days, $52 \mathrm{~g}$, and 141 days, respectively. Shika-Brown had the lowest $(p<0.05)$ age at first egg (119 days). Noiler and Shika-Brown had the highest $(p<0.05)$ egg weight $(56 \mathrm{~g})$ which was not significantly different from that of Kuroiler and Sasso. The peak HDEPs for Fulani (56.1\%), FUNAAB Alpha (63.9\%), Kuroiler (65.4\%), Noiler (55.6\%), Sasso (36.5\%), and ShikaBrown (68.1\%) were at 26, 26, 29, 41, 30, and 35 weeks, respectively. Feed intake per dozen eggs was lowest $(p<$ 0.05) for Shika-Brown $(2.9 \mathrm{~kg}$ ) and FUNAAB Alpha (2.9 $\mathrm{kg}$ ). Table 4 shows that age at first egg ranged from 116 (Shika-Brown) to 143 (Noiler) at Fol-Hope, and from 116 (Noiler) to 123 (Sasso) at FUNAAB. Shika-Brown and FUNAAB Alpha both had the highest $(p<0.05)$ HHEP at the two test stations. Feed per dozen eggs was lowest for FUNAAB Alpha (2.4) and Shika-Brown (2.6) at Fol-Hope, and Shika-Brown (3.2), Noiler (3.4), and FUNAAB Alpha (3.6) at FUNAAB. At Fol-Hope, the highest peak HDEP was observed at weeks 26 (75.3\%, FUNAAB Alpha) and 35 (70.7\%, Shika-Brown), while at FUNAAB, it was at weeks 25 (67.9\%, Fulani) and 33 (64.9\%, Shika-Brown). Figure 1 shows the average monthly THI for the entire test period, with an average of $28.8 \pm 1.8$ (Fol-Hope), and $29.4 \pm 1.9$ (FUNAAB) during the 13-month-laying phase. There was a total of 8 (FUNAAB) and 11 (Fol-Hope) months of normal- moderate (27.8-28.8), and 7 (Fol-Hope) and 10 (FUNAAB) months of severe-very severe $(28.9-\geq 30)$ THI values.

Table 5 shows the mortality rate of the breeds. Mortality during brooding ranged from $3.6 \%$ (Noiler) to $33.6 \%$ (Kuroiler). Noiler (13.5\%) and Sasso (23.7\%) had higher male mortalities during growing than Fulani (0\%), Shika-Brown (2.6\%), Kuroiler (5.4\%), and FUNAAB Alpha (7.9\%), but for females, Fulani had the highest mortality (39.1\%) while Sasso was lowest $(1.1 \%)$. The mortality rate for Shika-Brown (18.0\%), Noiler $(19.2 \%)$, and Fulani $(19.4 \%)$ was lower $(p<0.05)$ than Sasso (24.0\%), FUNAAB Alpha (24.8\%), and Kuroiler (24.5\%) during laying. The effect of location on mortality rate was only significant $(p<0.05)$ during the laying phase.

\section{Discussion}

The HES (70\% and $68.2 \%)$ and HFE (83.2\% and $83.7 \%)$ of both the foreign-sourced and locally sourced commercial hatchable eggs were similar. This suggests that apart from the genetics (Breeder flock and management), environmental factors such as proper storage and handling, general hatchery management, and appropriate incubator conditions are critical factors influencing hatchability of chicken eggs (Mauldin 2002). The HFE of all the breeds was within the range (52.4-87.0\%) previously reported for both indigenous and cross-bred chickens (Alabi et al., 2012; Tadesse, 2014; Wondmeneh et al., 2011). However, only HFE of Fulani was lower than the range (80-90\%) reported by MALDM (1993) for dual-purpose chicken breeds. The fertility and HFE of Fulani were low compared to the report by Adedeji et al. (2015) for Fulani chickens tested on-station (Fertility $85 \%$, HFE $84 \%$ ), but it was similar to that reported by Dunya et al. (2014) for Nigerian local chickens. The differences in the hatchability for Fulani may be associated with the variability within the Fulani population, since it is a localfarmer-developed strain (Olori 1992, Sonaiya 1998).

At 42 days, Kuroiler, Noiler, and Sasso had better growth performance than FUNAAB Alpha and Shika-Brown when compared with Fulani. The bodyweight gain over Fulani 


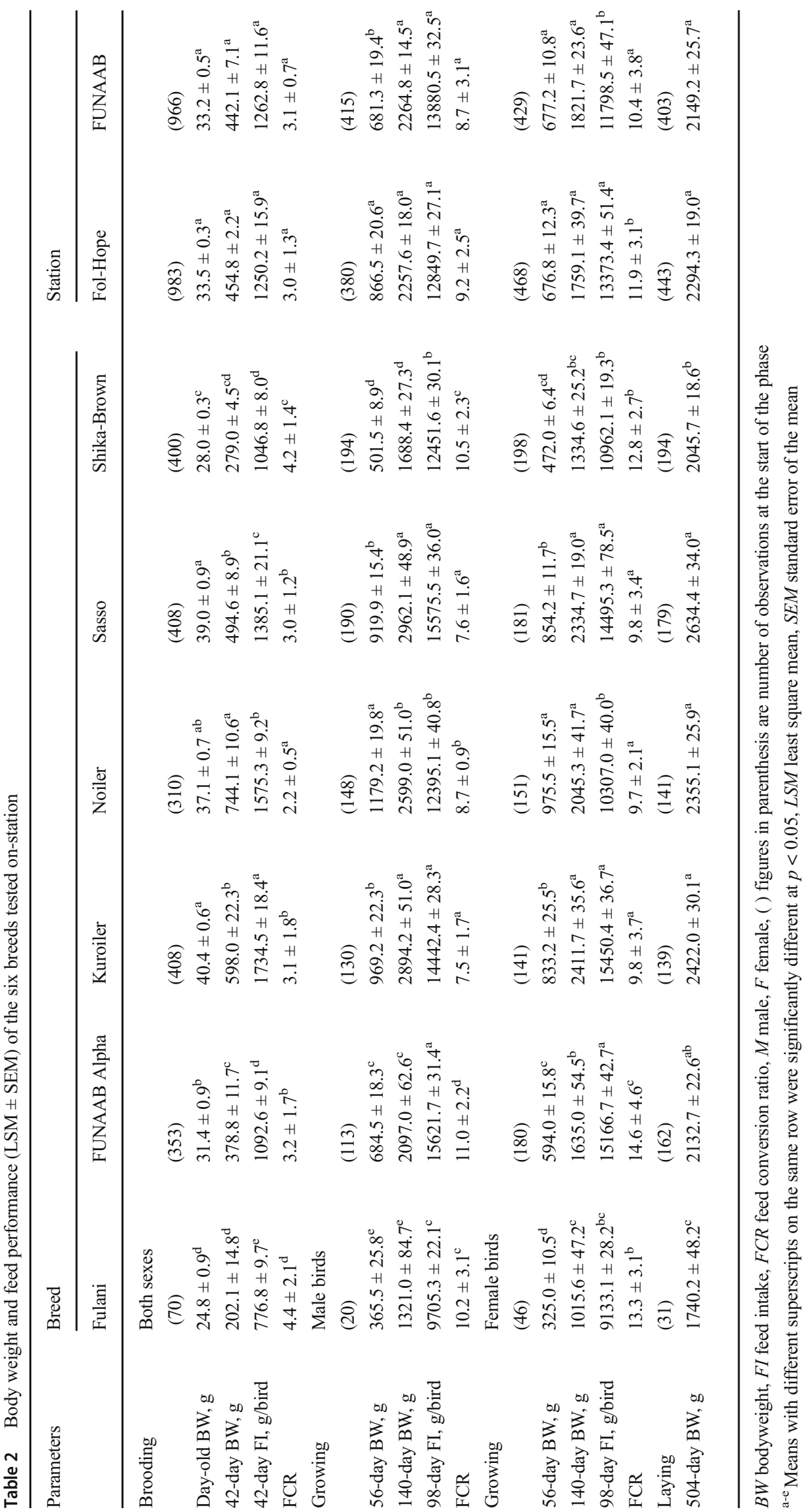


Table 3 Genotype by environment interaction $(\mathrm{LSM} \pm \mathrm{SEM})$ on laying performance at the test stations

\begin{tabular}{|c|c|c|c|c|c|c|c|c|}
\hline \multirow[t]{2}{*}{ Parameters } & \multicolumn{6}{|l|}{ Breed } & \multicolumn{2}{|l|}{ Station } \\
\hline & Fulani & $\begin{array}{l}\text { FUNAAB } \\
\text { Alpha }\end{array}$ & Kuroiler & Noiler & Sasso & Shika-Brown & Fol-Hope & FUNAAB \\
\hline Age at first egg, $d$ & $126 \pm 1.1^{\mathrm{c}}$ & $120 \pm 0.9^{\mathrm{b}}$ & $120 \pm 1.3^{\mathrm{b}}$ & $130 \pm 1.8^{\mathrm{d}}$ & $133 \pm 0.6^{\mathrm{d}}$ & $119 \pm 0.3^{\mathrm{a}}$ & $128 \pm 0.9^{\mathrm{b}}$ & $120 \pm 0.8^{\mathrm{a}}$ \\
\hline Egg weight, g & $39.6 \pm 0.3^{\mathrm{c}}$ & $49.0 \pm 0.0^{\mathrm{b}}$ & $54.0 \pm 0.1^{\mathrm{a}}$ & $55.6 \pm 0.0^{\mathrm{a}}$ & $54.9 \pm 0.3^{\mathrm{a}}$ & $56.3 \pm 0.1^{\mathrm{a}}$ & $51.2 \pm 0.1^{\mathrm{a}}$ & $52.1 \pm 0.3^{\mathrm{a}}$ \\
\hline HHEP, count & $88 \pm 3.4^{\mathrm{d}}$ & $190 \pm 2.8^{\mathrm{a}}$ & $127 \pm 4.2^{\mathrm{c}}$ & $173 \pm 2.1^{\mathrm{b}}$ & $75 \pm 5.6^{\mathrm{e}}$ & $192 \pm 0.7^{\mathrm{a}}$ & $142 \pm 2.1^{\mathrm{a}}$ & $138 \pm 2.5^{\mathrm{b}}$ \\
\hline HDEP, \% (week) & $56.1 \pm 8.3^{\mathrm{c}}(26)$ & $63.9 \pm 3.5^{\mathrm{b}}(26)$ & $65.4 \pm 6.5^{\mathrm{b}}(29)$ & $55.6 \pm 7.1^{\mathrm{c}}$ & $36.5 \pm 7.8^{\mathrm{d}}(30)$ & $68.1 \pm 5.9^{\mathrm{a}}(35)$ & $62.0 \pm 4.6^{\mathrm{a}}(34)$ & $43.4 \pm 3.9^{\mathrm{b}}(32)$ \\
\hline $\begin{array}{l}\text { Feed/dozen } \\
\text { eggs, kg }\end{array}$ & $4.4 \pm 2.1^{\mathrm{b}}$ & $2.9 \pm 1.3^{\mathrm{a}}$ & $4.4 \pm 1.8^{\mathrm{b}}$ & $3.6 \pm 0.9^{\mathrm{ab}}$ & $7.6 \pm 1.1^{\mathrm{c}}$ & $2.9 \pm 1.8^{\mathrm{a}}$ & $3.5 \pm 0.4^{\mathrm{a}}$ & $4.2 \pm 1.2^{\mathrm{b}}$ \\
\hline
\end{tabular}

HHEP hen-housed egg production, $H D E P \%$ lay at peak

${ }^{\mathrm{a}-\mathrm{e}}$ Means with different superscripts on the same row were significantly different at $p<0.05, L S M$ least square mean, SEM standard error of the mean

was $368 \%, 296 \%$, and $245 \%$ in Noiler, Kuroiler, and Sasso, respectively, while it was $187 \%$ in FUNAAB Alpha, and $138 \%$ in Shika-Brown. Noiler was the most efficient at converting feed to live bodyweight with $50 \%$ reduction in FCR compared to Fulani. During the growing phase, Kuroiler (249\%), Sasso (241\%), and Noiler (211\%) had higher mean live weights at 140 days for females, than FUNAAB Alpha (169\%), ShikaBrown (138\%), and Fulani (105\%) when compared with the mean live weight $(970 \mathrm{~g})$ reported by Adedokun and Sonaiya (2002) for female Nigerian local chickens. At 140 days, the male live weights of the improved breeds were 304\% (Sasso), 297\% (Kuroiler), 267\% (Noiler), 215\% (FUNAAB Alpha), 173\% (Shika-Brown), and $136 \%$ (Fulani) higher than the reported mean live weight ( $975 \mathrm{~g}$ ) of male Nigerian local chickens raised on-station (Ajayi, 2010; Akinokun, 1975; Nwosu and Asuquo, 1984). This shows a cluster of fast (i.e. $>200 \%$ higher male live weights: Sasso, Kuroiler, Noiler, and FUNAAB Alpha) and slow (i.e. $<200 \%$ higher male live weights: Shika-Brown and Fulani) growing breeds, with Sasso and Kuroiler being the most efficient converters of feed to live weight.
The laying performance of Shika-Brown, from the cluster of slow growing breeds, was significantly superior to that of the fast-growing breeds. This is not surprising as it has been established that bodyweight is negatively correlated with laying performance (Harms et al. 1982; Oluyemi and Roberts 1979). The HHEP of Shika-Brown, FUNAAB Alpha, and Noiler were $226 \%, 224 \%$, and $204 \%$ higher than the mean egg production of the Nigerian local chickens (85 eggs) reported by Adedokun and Sonaiya (2001), and Ajayi (2010). Also, the egg weight of Shika-Brown, Noiler, Sasso, and Kuroiler were over $140 \%$ higher than the mean egg weight ( $38 \mathrm{~g}$ ) of local chickens reported by Adedokun and Sonaiya (2001) for birds reared under similar conditions. There was a $22 \%$ reduction in the mean age at first egg of the improved breeds compared with the locals (160 days), and Shika-Brown and FUNAAB Alpha were the most efficient at converting feed to eggs. According to the selection criteria (over 200\% higher male live weight and egg production over local chickens) established by the ACGG project (https://africacgg.net/2016/ 01/13/program-meetings-set-stage-for-collaboration-and-on-

Table 4 Effect of location ( $\mathrm{LSM} \pm \mathrm{SEM}$ ) on age at first egg, hen-housed egg production, hen-day egg production and feed intake per dozen eggs of the breeds tested on-station

\begin{tabular}{|c|c|c|c|c|c|c|}
\hline Parameters & Fulani & FUNAAB Alpha & Kuroiler & Noiler & Sasso & Shika-Brown \\
\hline \multicolumn{7}{|l|}{ Fol-Hope station } \\
\hline Age at first egg, $d$ & $129 \pm 1.9^{\mathrm{c}}$ & $120 \pm 0.3^{\mathrm{b}}$ & $123 \pm 1.1^{\mathrm{b}}$ & $143 \pm 2.0^{\mathrm{d}}$ & $142 \pm 0.2^{\mathrm{d}}$ & $116 \pm 0.1^{\mathrm{a}}$ \\
\hline HHEP, count & $89 \pm 4.3^{\mathrm{d}}$ & $192 \pm 1.8^{\mathrm{a}}$ & $116 \pm 2.3^{\mathrm{c}}$ & $181 \pm 6.2^{\mathrm{b}}$ & $81 \pm 3.6^{\mathrm{d}}$ & $196 \pm 1.0^{\mathrm{a}}$ \\
\hline HDEP, \% (week) & $55.9 \pm 8.5^{\mathrm{c}}(26)$ & $75.3 \pm 6.7^{\mathrm{a}}(26)$ & $60.4 \pm 0.8^{\mathrm{b}}(25)$ & $61.2 \pm 7.3^{\mathrm{b}}(34)$ & $34.8 \pm 4.2^{\mathrm{d}}(26)$ & $70.7 \pm 0.6^{\mathrm{a}}(35)$ \\
\hline Feed/Dozen eggs, kg & $4.2 \pm 0.8^{\mathrm{b}}$ & $2.4 \pm 0.3^{\mathrm{a}}$ & $4.1 \pm 1.3^{\mathrm{b}}$ & $4.0 \pm 14^{\mathrm{b}}$ & $6.3 \pm 0.7^{\mathrm{c}}$ & $2.6 \pm 0.3^{\mathrm{a}}$ \\
\hline \multicolumn{7}{|l|}{ FUNAAB station } \\
\hline Age at first egg, $d$ & $122 \pm 0^{\mathrm{bc}}$ & $119 \pm 1.3^{\mathrm{ab}}$ & $117 \pm 0.6^{\mathrm{a}}$ & $116 \pm 1.5^{\mathrm{a}}$ & $123 \pm 0.6^{\mathrm{c}}$ & $122 \pm 0.1^{\mathrm{bc}}$ \\
\hline HHEP, count & $86 \pm 3.1^{\mathrm{d}}$ & $187 \pm 1.2^{\mathrm{a}}$ & $138 \pm 7.1^{\mathrm{c}}$ & $162 \pm 5.8^{\mathrm{b}}$ & $67 \pm 4.2^{\mathrm{e}}$ & $188 \pm 9.2^{\mathrm{a}}$ \\
\hline HDEP, \% (week) & $67.9 \pm 9.7^{\mathrm{a}}(25)$ & $54.9 \pm 6.2^{\mathrm{b}}(54.9)$ & $47.1 \pm 3.9^{\mathrm{c}}(32)$ & $56.7 \pm 4.0^{\mathrm{b}}(42)$ & $26.1 \pm 1.3^{\mathrm{d}}(30)$ & $64.9 \pm 5.1^{\mathrm{a}}(33)$ \\
\hline Feed/Dozen eggs, kg & $4.9 \pm 1.1^{\mathrm{b}}$ & $3.6 \pm 0.6^{\mathrm{a}}$ & $5.1 \pm 2.1^{\mathrm{b}}$ & $3.4 \pm 0.2^{\mathrm{a}}$ & $10.8 \pm 0.4^{\mathrm{c}}$ & $3.2 \pm 2.2^{\mathrm{a}}$ \\
\hline
\end{tabular}

HHEP hen-housed egg production, HDEP \% lay at peak

${ }^{\mathrm{a}-\mathrm{e}}$ Means with different superscripts on the same row were significantly different at $p<0.05, L S M$ least square mean, SEM standard error of the mean 
Fig. 1 Average temperature humidity index (THI) during the test period at the on-station centres

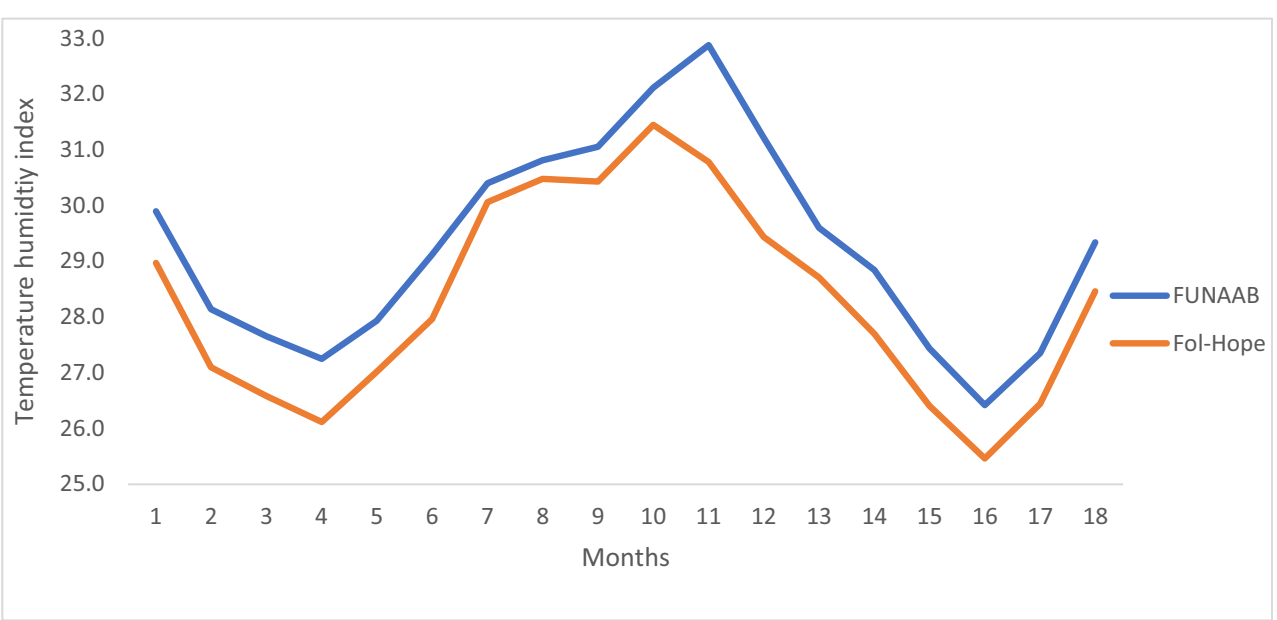

farm-trials-of-improved-chicken-breeds-in-africa) for SHPSHG, only FUNAAB Alpha and Noiler attained both the $200 \%$ higher live weight, and $200 \%$ higher egg production over the Nigerian local chickens. However, Sasso and Kuroiler achieved over $200 \%$ male live weight only, and Shika-Brown also achieved only over $200 \%$ egg production, compared with the local chickens.

The peak HDEP for all the breeds, except Sasso, was higher than the range (44.7-54.9\%) previously reported by Adedokun and Sonaiya (2001) for Nigerian local chickens. Overall, the THI, at both Fol-Hope (30.5-30.4) and FUNAAB (30.8-31.1), was observed to plateau between the 8th and 9th months, when the peak HDEP (weeks 32-34) was recorded. This suggests that in addition to maintaining a normal $(<27.8)$ to moderate $(27.8-28.8)$ THI-based stress indicator ranges, the relative stability of THI during rearing also enhances laying performance. Over $50 \%$ (10 months) of the total test period at FUNAAB were under severe to very severe (28.9- $\geq 30$ ) THI thresholds, as against a total of 7 months (39\%) at Fol-Hope. The laying phase is accounted for $90 \%$ (9 months) of the entire months with the severe to very severe THI values at FUNAAB. The birds tested in the southern Guinea savanna (Fol-Hope) had lower feed per dozen eggs (3.5), and higher HHEP (142), and HDEP (62\%) compared with the dry lowland rainforest (FUNAAB). This superior laying performance could be due to the moderate THI (28.8) compared with the severe THI at FUNAAB (29.4) because egg production decreases with increasing THI values and heat stress (Kilic and Simsek 2013; Mashaly et al. 2004; Sterling et al. 2003).

Overall, the locally sourced breeds had lower mortality rates (brooding $7.3 \%$, growing $8.2 \%$, and laying $20.5 \%$ ) than the foreign-sourced breeds (Brooding $21.3 \%$, growing $8.7 \%$, and laying $24.2 \%$ ) which suggests that the locally sourced breeds were more adaptable to the environment than the foreign breeds. High mortality rates are reportedly associated with weakened immune systems, resulting from high levels of temperature-induced stress and inability of animals to efficiently thermoregulate (Al-Awadi et al., 1995; Furlan and Macari 2002; Mashaly et al., 2004; Mumma et al., 2006; Perreira et al., 2010). According to Ajakaiye et al. (2011) and Tao and Xin (2003), high mortality, as influenced by heat stress, also depends on the physiological state and adaptability of the breed to its prevailing environmental conditions. In addition to THI, age and bodyweight are predisposing factors to high incidence of mortality in poultry (Perreira et al. 2010). Generally, across the two stations, mortality increased from day-old to the end-of-testing, at 504 days old. In this study, there was an increased

Table 5 Mortality rates (LSM \pm SEM) of the six breeds tested on-station

\begin{tabular}{|c|c|c|c|c|c|c|c|c|}
\hline \multirow[t]{2}{*}{ Phases } & \multicolumn{6}{|l|}{ Breed } & \multicolumn{2}{|l|}{ Station } \\
\hline & Fulani & FUNAAB Alpha & Kuroiler & Noiler & Sasso & Shika Brown & Fol-Hope & FUNAAB \\
\hline Brooding, Mortality \% & $5.7 \pm 0.7^{\mathrm{c}}$ & $16.9 \pm 1.0^{\mathrm{e}}$ & $33.6 \pm 2.9^{\mathrm{f}}$ & $3.6 \pm 0.6^{\mathrm{b}}$ & $9.1 \pm 1.8^{\mathrm{d}}$ & $2.0 \pm 0.1^{\mathrm{a}}$ & $13.7 \pm 0.8^{\mathrm{a}}$ & $12.6 \pm 1.2^{\mathrm{a}}$ \\
\hline Growing, male Mortality, \% & $0.0^{\mathrm{a}}$ & $9.7 \pm 1.4^{\mathrm{d}}$ & $5.4 \pm 2.6^{\mathrm{c}}$ & $13.5 \pm 2.1^{\mathrm{e}}$ & $23.7 \pm 3.6^{\mathrm{f}}$ & $2.6 \pm 0.8^{b}$ & $13.0 \pm 2.9^{\mathrm{a}}$ & $11.4 \pm 1.3^{\mathrm{a}}$ \\
\hline Growing, female Mortality, \% & $39.1 \pm 0.9^{\mathrm{d}}$ & $10.0 \pm 2.5^{\mathrm{c}}$ & $1.4 \pm 0.0^{\mathrm{a}}$ & $6.6 \pm 1.8^{\mathrm{b}}$ & $1.1 \pm 0.1^{\mathrm{a}}$ & $2.0 \pm 0.1^{\mathrm{a}}$ & $5.5 \pm 1.8^{\mathrm{a}}$ & $5.8 \pm 2.3^{\mathrm{a}}$ \\
\hline Laying, mortality, $\%$ & $19.4 \pm 1.3^{\mathrm{a}}$ & $24.8 \pm 4.4^{\mathrm{b}}$ & $24.5 \pm 2.1^{\mathrm{b}}$ & $19.2 \pm 3^{\mathrm{a}}$ & $24.0 \pm 2.2^{\mathrm{b}}$ & $18.0 \pm 1.7^{\mathrm{a}}$ & $16.0 \pm 3.2^{\mathrm{b}}$ & $28.3 \pm 2.9^{\mathrm{a}}$ \\
\hline
\end{tabular}

${ }^{\mathrm{a}-\mathrm{e}}$ Means with different superscripts on the same row were significantly different at $p<0.05$

LSM least square mean, SEM standard error of the mean 
mortality rate of female birds between the growing and laying phase for all the breeds, except Fulani. This may be due to the heavier bodyweight of the other breeds which presents a higher metabolic activity, and the challenge of maintaining adequate thermoregulation under heat stress (Furlan and Macari 2002; Lin et al. 2006).

The low mortality observed during brooding for the locally sourced breeds, compared with the foreign breeds, suggests that the locally sourced breeds were more adaptable to the environment and could withstand the post-hatch stress and physiological changes accompanying early chick life (Yassin et al., 2009) better than the foreign breeds. Also, at the growing phase, females $(6.0 \%)$ had a lower mean mortality rate than males (11.1\%) which according to Leitner et al. (1989), may be associated with a generally less efficient immune response in male chickens.

The locally sourced breeds were more adapted than the foreign-sourced breeds. The breeds were differentiated into two clusters of faster-growing (Sasso, Kuroiler, Noiler, FUNAAB Alpha) and slower-growing (ShikaBrown, and Fulani) breeds. The faster-growing breeds had over $200 \%$ higher bodyweight compared with the local, unimproved chickens, while the HHEP of ShikaBrown, FUNAAB Alpha, and Noiler was over $200 \%$ higher than the local chickens. Based on the growth and laying performance, Noiler and FUNAAB Alpha were observed to have dual-purpose functions (i.e. for BW and egg production). On the other hand, both Kuroiler and Sasso were observed to have singlepurpose function for meat (BW), while Shika-Brown was most suitable for egg production. The overall ranking (i.e. highest to lowest) of the breeds across the rearing phases based on growth (Final live weight and FCR) and laying performance (Age at first egg, egg weight, HHEP, HDEP and feed/dozen eggs) and survivability is Shika-Brown, Noiler, Kuroiler, Sasso, FUNAAB Alpha, and Fulani.

Acknowledgement This research was carried out under the International Livestock Research Institute (ILRI)-led African Chicken Genetic Gains (ACGG) project sponsored by Bill and Melinda Gates Foundation (Grant Agreement OPP1112198). We are grateful to the management of FolHope Farms Ltd, Oyo State, and PEARL Poultry Unit, FUNAAB, Ogun State.

\section{Compliance with ethical standards}

Conflict of interest The authors declare that they have no conflict of interest.

Statement of animal rights All applicable international, national, and institutional guidelines for the care and use of animals were followed. Study was approved by International Livestock Research Institute Institutional Animal Care and Use Committee (ILRI IACUC) with reference number: IACUC-RC2016.26.
Open Access This article is licensed under a Creative Commons Attribution 4.0 International License, which permits use, sharing, adaptation, distribution and reproduction in any medium or format, as long as you give appropriate credit to the original author(s) and the source, provide a link to the Creative Commons licence, and indicate if changes were made. The images or other third party material in this article are included in the article's Creative Commons licence, unless indicated otherwise in a credit line to the material. If material is not included in the article's Creative Commons licence and your intended use is not permitted by statutory regulation or exceeds the permitted use, you will need to obtain permission directly from the copyright holder. To view a copy of this licence, visit http://creativecommons.org/licenses/by/4.0/.

\section{References}

Adedeji, T.A, Amao, S.R, Popoola, A.D, and Ogundipe, R.I. 2015. Fertility, hatchability and egg quality traits of Nigerian locally adapted chickens in the derived savanna environment of Nigerian Journal of Biology, Agriculture and Healthcare, 5(17): 36-42

Adedokun, S.A. and Sonaiya, E.B. 2001. Comparison of the performance of Nigerian indigenous chickens from three agro-ecological zones. Livestock Research for Rural Development 13(15) http://www.lrrd. org/lrrd13/2/aded132.htm. Accessed on August 20, 2019

Adedokun, S.A. and Sonaiya, E.B. 2002. Crossbreeding Nigeria indigenous with the Dahlem Red chickens for improved productivity and adaptability. Archiv Tierzucht Dummerstorf, 45(3): 297-305.

ACGG (African Chicken Genetic Gains) Nigeria baseline data 2016. http://data.ilri.org/portal/dataset.

Ajakaiye, J.J., Perez-Bello, A. and Mollineda-Trujillo, A. 2011. Impact of heat stress on egg quality in layer hens supplemented with 1-ascorbic acid and dl-tocopherol acetate. Veterinarski Arhiv, 81:119-132.

Ajayi, F.O. 2010. Nigerian indigenous chicken: A valuable genetic resource for meat and egg production. Asian Journal of Poultry Science, 4:164-172

Akinokun, O. 1975. The Ife foundation stock of Nigeria chicken. (1) Body weight, egg production and sexual maturity. Nigerian Agriculture Journal 12: 232-239

Alabi, O.J., Ng`ambi, J.W., Norris, D. and Mabelebele, M. 2012. Effect of egg weight on hatchability and subsequent performance of Potchefstroom Koekoek chicks. Asian Journal of Animal and Veterinary Advances 7: 718-725.

Al-Awadi, A.A., Husseini, M.D., Diab, M.F. and Al-Nasser, A.Y. 1995. Productive performance of laying hens housed in minimal shade floor pens and laying cages under ambient conditions in hot arid regions. Livestock Production Science, 41:263-269.

Dunya, A.M., Husa, H., Yusuf, S.Z., Usman, Y. and Makinta, A.A. 2014. Fertility and hatchability in local chicken of Borno state, Nigeria Journal of Agricultural Science Applications 3: 20-23.

FAO 2010. Chicken genetic resources used in smallholder production systems and opportunities for their development, by P. Sørensen. FAO Smallholder Poultry Production Paper No. 5. Rome.

FAO 2015. Comparative performance of Sonali chickens, commercial broilers, layers and local non-descript (deshi) chickens in selected areas of Bangladesh. Animal Production and Health Working Paper. No. 14. Rome.

Furlan, R.L. and Macari, M. 2002. Termorregulação. In: M. Macari, R.L. Furlan and E. Gonzales (eds), Fisiologia aviária aplicada a frangos de corte. Jaboticabal, 2002 (FUNEP), 209-230.

Galukande, E., Alinaitwe J. and Mudondo, H. 2016. Improving livelihoods of the urban poor in Kampala city through Kuroiler chicken production. Proceedings of the Conference on International 
Research on Food Security, Natural Resource Management and Rural Development, Tropentag 2016, Vienna, Austria.

Harms, R. H., Costa, T. P. and Miles R. D. 1982. Daily feed intake and performance of laying hens grouped according to body weight. Poultry Science 6(16): 1021- 128.

Kilic, I. and Simsek, E. 2013. The effects of heat stress on egg production and quality of laying hens. Journal of Animal and Veterinary Advances, 12(1): 42-47.

Lallo, C.H.O., Cohen, J., Rankine, D., Taylor, M., Cambell, J. and Stephenson, T. 2018. Characterising heat stress on livestock using the temperature humidity index (THI)-prospects for a warmer carribean. Regional Environmental Change 18(8): 2329-2340. https://doi.org/10.1007/s10113-018-1359-x.

Leitner, G., Heller, E.D. and Friedman, A. 1989. Sex-related differences in immune response and survival rate of broiler chickens. Veterinary Immunology and Immunopathology, 21(3-4):249-60.

Lin, H., Jiao, H.C., Buyse, J. and Decuypere, E. 2006. Strategies for preventing heat stress in poultry. World's Poultry Science Journal, 62:71-85.

Mauldin, J.M. 2002. Factors affecting hatchability. In: D.D. Bell, and W.D. Weaver (eds), Commercial chicken meat and egg production. Springer, Boston, 727-723.

Mashaly, M.M., Hendricks, G.L., Kalama, M.A., Gehad, A.E., Abbas, A.O. and Patterson, P.H. 2004. Effect of heat stress on production parameters and immune responses of commercial laying hens. Poultry Science, 83:889-894.

Mumma, J.O., Thaxton, J.P., Vizzier-Thaxton, Y. and Dodson, W.L. 2006. Physiological stress in laying hens. Poultry Science, 85:761769.

MALDM 1993. Ministry of Agriculture Livestock Development and Marketing Kenya. Animal Production Division. Annual Report.

NiMET 2019. Nigerian Meteorological Agency daily weather for 20162018. https://nimet.gov.ng/daily-weather.

Nwosu, C.C. and Asuquo, B.O. 1984. Heritability estimates of bodyweight in the local chickens. Proceedings of the $9^{\text {th }}$ annual conference of the Nigerian Society for Animal Production, 41-48.

Olori, V. E. 1992. Genetic evaluation of local chickens (Fulani and Yoruba strains) of Nigeria, (unpublished M.Sc. thesis, Obafemi Awolowo University, Ile-lfe.)

Oluyemi, J. A. and Roberts, F. A. 1979. Poultry Production in Warm Wet Climate. Mac Millan Press Ltd, London
Perreira, D.F., do Vale, M.M., Zevolli, B.R. and Salgado, D.D. 2010. Estimating mortality in laying hens as the environmental temperature increases. Brazilian Journal of Poultry Science 12(4): 265-271.

Sharma, J., Xie, J., Boggess, M., Galukande, E., Semambo, D. and Sharma, S. 2015. Higher weight gain by Kuroiler chickens than indigenous chickens raised under scavenging conditions by rural households in Uganda. Livestock Research for Rural Development 27 (9). http://www.lrrd.org/lrrd27/9/shar27178.html. Accessed Oct. 2017

Sonaiya, E.B. 1990. Poultry husbandry in small rural farms. Entwicklung + ländlicher raum 4: 3-6.

Sonaiya, E.B. 1998. Energy Flux and Animal Product. Inaugural Lecture 125. Obafemi Awolowo University Press Limited, Ile-Ife, Nigeria. ISSN: 0189-7845. https://ir.oauife.edu.ng/bitstream/handle/ 123456789/4113/Emmanuel\%20Babafunso\%20Sonaiya.pdf? sequence $=1 \&$ isAllowed $=\mathrm{y}$

Sterling, K.G., Bell, D.D., Pesti, G.M. and Aggrey, S.E. 2003. Relationships among strain, performance and environmental termperature in commercial laying hens. Journal of Applied Poultry Research, 12:85-91

Tadesse, A. 2014. Production and reproduction performance of rural poultry in lowland and midland agro-ecological zones of central Tigray, Northern Ethiopia, British Poultry Science, 3(1): 6-14.

Tao, X. and Xin, H. 2003. Acute synergistic effects of air temperature, humidity, and velocity on homeostasis of market-size broilers. Transactions of the American Society of Agricultural Engineers, 46:491-497. https://doi.org/10.13031/2013.12971.

Wondmeneh, E., Dawud, I. and Adey, M. 2011. Comparative evaluation of fertility and hatchability of Horro, Fayoumi, Lohmann Silver and Potchefstroom Koekoek breeds of chicken, Asian Journal of Poultry Science, 5: 124-129.

Yassin, Y., Velthuis, A.G.J., Boerjan, M. and Van Riel, J. 2009. Field study on broilers' first-week mortality, Poultry Science, 88(4): 798-804.

https://africacgg.net/2016/01/13/program-meetings-set-stage-forcollaboration-and-on-farm-trials-of-improved-chicken-breeds-inafrica/. Accessed 10 Oct 2019.

Publisher's note Springer Nature remains neutral with regard to jurisdictional claims in published maps and institutional affiliations. 